\title{
Prevention of dental caries with remineralization in containing Casein Phosphopeptid-Amorphous Calcium Phosphate (CPP-ACP) to students SD Swasta Muhammadiyah - 03 Medan
}

\author{
Fitri Yunita Batubara ${ }^{1 *}$, M. Zulkarnain ${ }^{2}$, Cut Nurliza $^{1}$, Nurdiana $^{3}$, Dewi Kartika ${ }^{4}$ \\ ${ }^{1}$ Department of Dental Conservation, Faculty of Dentistry, Universitas Sumatera Utara \\ ${ }^{2}$ Department of Prosthodontics, Faculty of Dentistry, Universitas Sumatera Utara \\ ${ }^{3}$ Department of Oral Medicine, Faculty of Dentistry, Universitas Sumatera Utara \\ ${ }^{4}$ Department of Dental Radiology, Faculty of Dentistry, Universitas Sumatera Utara \\ *Email: fitri.yunita@usu.ac.id
}

\begin{abstract}
Dental caries is an infectious disease caused by demineralization of enamel and dentin which is closely related to the consumption of cariogenic foods. Generally children entering school age have a high caries risk, because at this school age children usually like food and drink snacks as they wish. The impact that occurs when since the beginning has experienced caries is in addition to the function of the teeth as chewing that is disrupted, swollen gums, the child will also experience disturbances in carrying out their daily activities, so the child will not eat and consequently malnutrition can occur, this causes the child to be unable to study because of lack of concentration so that it will affect intelligence.

The results of the field analysis and preliminary interviews with school leaders as partners in community service obtained data that students in Muhammadiyah Private Elementary School 03 Medan aged 6-8 years experienced dental caries with the characteristics of cavities, porous, and stains / plaques. These characteristics are related to the patterns or behavior of students who like to consume sweet foods like candy, bread, and chocolate. School Dental Health Efforts (UKGS) have also not been implemented in schools. Therefore, community service is needed to be carried out with a form of socialization prevention for early caries in order to provide knowledge of the main causes, ways of spreading, impact, efforts to prevent dental caries, and providing remineralization (dental caries prevention) containing Casein Phosphopeptid-Amorphous Calcium Phosphate (CPP-ACP) to students of grade II Muhammadiyah Primary School 03 Medan.

Community service activities were carried out by five service teams from the Faculty of Dentistry, University of North Sumatra on August 27, 2019, involving as many as twenty two USU FKG students who were undergoing clinical clerkship. The socialization and provision of caries prevention materials to 111 students who were in grade II of Muhammadiyah Primary School - 03 Medan.
\end{abstract}

Keyword: Casein Phosphopeptid-Amorphous Calcium Phosphate (CPP-ACP), dental caries, remineralization

Abstrak
Karies gigi merupakan penyakit infeksi yang disebabkan oleh demineralisasi email dan dentin yang erat
hubungannya dengan konsumsi makanan yang kariogenik. Umumnya anak-anak memasuki usia sekolah
mempunyai resiko karies yang tinggi, karena pada usia sekolah ini anak-anak biasanya suka jajan makanan dan
minuman sesuai keinginannya. Dampak yang terjadi bila sejak awal sudah mengalami karies adalah selain fungsi
gigi sebagai pengunyah yang terganggu, gusi bengkak, anak juga akan mengalami gangguan dalam menjalankan
aktifitasnya sehari-hari, sehingga anak tidak mau makan dan akibatnya bisa terjadi malnutrisi, hal ini
menyebabkan anak tidak dapat belajar karena kurang berkonsentrasi sehingga akan mempengaruhi kecerdasan.
Hasil analisis lapangan dan wawancara pendahuluan dengan pimpinan sekolah sebagai mitra dalam
pengabdian masyarakat ini diperoleh data bahwa pada Siswa SD Swasta Muhammadiyah - 03 Medan yang berusia
6-8 tahun mengalami karies gigi dengan ciri-ciri gigi berlubang, keropos, dan terdapat noda/plak. Ciri tersebut
berkaitan dengan pola atau perilaku siswa yang gemar mengkonsumsi makanan manis seperti permen, roti, dan
cokelat. Usaha Kesehatan Gigi Sekolah (UKGS) juga belum dilaksanakan di sekolah. Oleh karena itu perlu
diadakan pengabdian kepada masyarakat dengan bentuk kegiatan sosialisasi pencegahan karies dini dalam rangka 
memberikan pengetahuan akan penyebab utama, cara penyebaran, dampak, upaya pencegahan karies gigi, dan pemberian bahan remineralisasi (pencegah karies gigi) yang mengandung Casein Phosphopeptid-Amorphous Calcium Phosphate (CPP-ACP) kepada para siswa kelas II SD Swasta Muhammadiyah - 03 Medan.

Kegiatan pemgabdian kepada masyarakat ini dilaksanakan oleh lima orang tim pengabdi yang berasal dari Fakultas Kedokteran Gigi Universitas Sumatera Utara pada tanggal 27 Agustus 2019 dengan melibatkan sebanyak dua puluh dua orang mahasiswa FKG USU yang sedang menjalani kepaniteraan klinik. Sosialisasi dan pemberian bahan pencegah karies kepada 111 orang siswa yang kelas II SD Swasta Muhammadiyah - 03 Medan.

Kata Kunci: Casein Phosphopeptid-Amorphous Calcium Phosphate (CPP-ACP), karies gigi, remineralisasi

\section{PENDAHULUAN}

Karies gigi merupakan penyakit gigi dan mulut yang multifaktorial artinya adalah karies dapat terjadi apabila terdapat faktor penyebab yang saling berhubungan dan mendukung, yaitu host (gigi dan saliva), mikroorganisme, substrat, dan waktu (Casamassimo, Fields, McTigue, Nowak, 2013). Kirakira $90 \%$ dari anak-anak usia sekolah di seluruh dunia dan sebagian besar orang dewasa pernah menderita karies. Karies gigi merupakan penyakit yang terdapat pada jaringan keras gigi yaitu email, dentin dan sementum yang mengalami proses kronis regresif. Karies menyerang jaringan keras gigi yang ditandai dengan adanya demineralisasi jaringan keras gigi yang kemudian diikuti oleh kerusakan bahan organiknya (Mitchell, 2014).

Umumnya anak-anak memasuki usia sekolah mempunyai risiko karies yang tinggi, karena pada usia sekolah ini anak-anak biasanya suka jajan makanan dan minuman sesuai keinginannya. Kebiasaan ini merupakan salah satu faktor penyebab yang multifaktorial (Brown dan Dodds, 2008). Dampak yang terjadi bila sejak awal sudah mengalami karies adalah selain fungsi gigi sebagai pengunyah yang terganggu, gusi bengkak, anak juga akan mengalami gangguan dalam menjalankan aktifitasnya sehari-hari, sehingga anak tidak mau makan dan akibatnya bisa terjadi malnutrisi, hal ini menyebabkan anak tidak dapat belajar karena kurang berkonsentrasi sehingga akan mempengaruhi kecerdasan. Bila gigi sulung sudah berlubang dan rusak maka dapat diramalkan gigi dewasanya tidak akan sehat nantinya (Sumini, 2014).

Casein phosphopeptides merupakan salah satu bahan remineralisasi terbaru yang digunakan dalam pencegahan karies gigi. Agen ini dapat digunakan sebagai CPP-ACP (casein phophopeptides with amorphous calcium phosphate). CPP-ACP menunjukkan penurunan demineralisasi dan peningkatan remineralisasi pada permukaan lesi karies dini. Peran utama dari casein phosphopeptides adalah memodulasi bioavailability level calcium phosphate dengan memelihara supersaturasi ion fosfor $(\mathrm{P})$ dan kalsium $(\mathrm{Ca})$ untuk meningkatkan remineralisasi. ACP juga mengontrol presipitasi CPP dengan ion Ca dan P. CPP juga terdeteksi memiliki efek antibakterial dan sebagai buffer terhadap plak dan menghambat pertumbuhan serta perlekatan Streptococcus mutans dan Streptococcus sorbinus (Reynolds, 2004).

Hasil analisis lapangan dan wawancara pendahuluan dengan pimpinan sekolah sebagai mitra dalam pengabdian masyarakat ini diperoleh data bahwa pada Siswa SD Swasta Muhammadiyah 03 Medan yang berusia 6-8 tahun mengalami karies gigi dengan ciri-ciri gigi berlubang, keropos, dan terdapat noda/plak. Ciri tersebut berkaitan dengan pola atau perilaku siswa yang gemar mengkonsumsi makanan manis seperti permen, roti, dan cokelat. Usaha Kesehatan Gigi Sekolah (UKGS) juga belum dilaksanakan di sekolah. Oleh karena itu perlu diadakan kegiatan sosialisasi pencegahan karies dini dalam rangka memberikan pengetahuan akan penyebab utama, cara penyebaran, dampak, upaya pencegahan karies gigi, dan pemberian bahan remineralisasi (pencegah karies gigi) yang mengandung Casein Phosphopeptid-Amorphous Calcium Phosphate (CPP-ACP) kepada para siswa kelas II SD Swasta Muhammadiyah - 03 Medan. 


\section{METODE PELAKSANAAN (METHODS)}

Pelaksanaan kegiatan sosialisasi pencegahan karies dilaksanakan SD Swasta Muhammadiyah - 03 Medan dengan mengambil siswa kelas II yang berjumlah sekitar 111 orang yang dibagi ke dalam tiga ruang kelas, yaitu:

1. Kelas II A+ sebanyak 20 orang siswa dan Kelas II B+ sebanyak 20 orang siswa

2. Kelas II A sebanyak 35 orang siswa

3. Kelas II B sebanyak 36 orang siswa

Kegiatan dilakukan secara paralel dalam waktu 1 (satu) hari. Metode dan teknik sosialisasi meliputi pelaksanaan promosi kesehatan dengan menggunakan metode ceramah, dibantu dengan adanya tayangan powerpoint yang menarik untuk anak-anak. Bentuk kegiatan pengabdian yang dilakukan adalah bentuk sosialisasi pencegahan karies, pengenalan dan pemberian bahan remineralisasi yang mengandung Casein Phosphopeptid-Amorphous Calcium Phosphate (CPPACP) kepada para siswa kelas II SD Swasta Muhammadiyah - 03 Medan. Susunan kegiatan sosialisasi adalah sebagai berikut:

1. Persiapan acara pengabdian masyarakat.

2. Pembukaan yang dilakukan oleh pengabdi di masing-masing ruangan secara paralel.

3. Penyampaian materi dengan metode ceramah, dibantu dengan menggunakan slide.

4. Aplikasi bahan remineralisasi yang mengandung Casein Phosphopeptid-Amorphous Calcium Phosphate (CPP-ACP) kepada para siswa secara langsung dengan dipandu oleh tim pemgabdian kepada masyarakat FKG USU.

5. Pembagian bahan remineralisasi untuk dibawa siswa ke rumah.

6. Penutupan.

\section{HASIL DAN PEMBAHASAN}

Kegiatan pengabdian masyarakat ini dimulai dengan survey awal terkait lokasi dan sasaran pengabdian masyarakat. Peserta yang terlibat dalam kegiatan ini adalah kelas II SD Swasta Muhammadiyah - 03 Medan. Kegiatan sosialisasi berjalan dengan baik, lancar, dan disambut antusias oleh seluruh siswa karena berkaitan erat dengan kesehatan gigi dan mulut sebagai bagian dari angota tubuh. Penyampaian materi dilaksanakan langsung oleh dokter gigi yang ahli dibidangnya dengan bantuan powerpoint dengan menampilkan gambar- gambar yang menarik. Penyampaian materi dilakukan sekitar 15 menit. Materi sosialisasi meliputi penyebab utama, cara penyebaran, dan dampak karies gigi serta upaya pencegahan yang dapat dilakukan untuk menghindari terjadinya karies gigi. Kegiatan dilanjutkan dengan tanya jawab dan latihan mengaplikasikan bahan anti karies yang mengandung Casein Phosphopeptid-Amorphous Calcium Phosphate (CPP-ACP) ke gigi siswa.

Karies gigi dapat dialami oleh setiap orang dan dapat timbul pada satu permukaan gigi atau lebih dan dapat meluas ke bagian yang lebih dalam dari gigi, misalnya: dari email ke dentin atau ke pulpa. Karies gigi dapat terdapat di seluruh dunia, tanpa memandang umur, bangsa ataupun keadaan ekonomi.

Faktor-faktor yang menyebabkan mudahnya terjadi karies gigi pada gigi desidui adalah struktur enamel gigi desidui kurang solid dan lebih tipis, serta morfologi luar gigi desidui lebih memungkinkan retensi makanan dibandingkan gigi tetap, selain itu keadaan kebersihan mulut anak pada umumnya lebih jelek dan anak pada umumnya lebih banyak serta sering memakan makanan dan minuman yang kariogenik dibandingkan orang dewasa.

Dokter gigi harus berupaya untuk mendidik pasiennya mengenai cara-cara pencegahan karies dan tentu saja merupakan tanggung jawab dokter gigi untuk mendidik masyarakat. Agar menjadi lebih efektif, cara-cara yang digunakan pada pendidikan kesehatan gigi harus direncanakan dan dilaksanakan dengan profesional.

Pada saat ini perawatan karies dilakukan dengan pendekatan kontemporer. Intervensi noninvasif dari lesi karies yang belum membentuk kavitas diperoleh dengan menggunakan bahan 
terapeutik untuk penyembuhan lesi. Upaya untuk mencegah karies antara lain dengan melakukan intervensi terhadap interaksi bakteri S.mutans dan permukaan gigi. Agen anti karies yang sering dipakai saat ini adalah Casein Phosphopeptid-Amorphous Calcium Phosphate (CPP-ACP). CPPACP akan menyebabkan penurunan demineralisasi dan peningkatan remineralisasi pada permukaan lesi karies dini. Peran utama dari casein phosphopeptides adalah memodulasi bioavailability level calcium phosphate dengan memelihara supersaturasi ion fosfor $(\mathrm{P})$ dan kalsium $(\mathrm{Ca})$ untuk meningkatkan remineralisasi

Memeriksakan gigi secara teratur ke dokter gigi merupakan keharusan untuk mempertahankan kesehatan gigi. Pemeliharaan kesehatan gigi lebih utama daripada perawatan yang dilakukan oleh dokter gigi. Hal ini penting ditekankan dalam pencegahan penyakit gigi dan mulut karena banyak orang menganggap bahwa yang diperlukan hanyalah pergi ke dokter gigi secara teratur.

\section{KESIMPULAN}

Dari hasil kegiatan pengabdian kepada masyarakat yang telah dilaksanakan oleh tim pengabdi dapat disimpulkan bahwa :

1. Pelaksanaan kegiatan sosialisasi pencegahan karies telah dilaksanakan SD Swasta Muhammadiyah - 03 Medan dengan mengambil seluruh siswa kelas II sejumlah 111 orang yang berusia 6-8 tahun.

2. Kegiatan pengabdian masyarakat ini bertujuan untuk menanamkan kebiasaan menjaga kesehatan gigi dan mulut serta upaya pelaksanaan pencegahan karies gigi untuk memelihara dan mempertinggi derajat kesehatan giginya sejak dini sehingga tidak terjadi gangguan fungsi, aktivitas (belajar dan bekerja) dan penurunan produktivitas kerja yang tentunya akan mempegaruhi kualitas hidup jangka panjang.

3. Upaya pencegahan karies gigi yang dapat dilakukan peserta pengabdian masyarakat antara lain menggosok gigi secara teratur, memperhatikan pola makan, melakukan kunjungan ke dokter gigi secara rutin, mengontrol dan mengindari kebiasaan makan yang buruk (makan makanan manis atau asam secara berlebihan.

Adapun yang menjadi saran pada pengabdian kepada masyarakat selanjutnya antara lain:

1. Jumlah siswa SD yang menjadi peserta ditingkatkan agar tujuan meningkatkan kesehatan gigi dan mulut dapat mencakup banyak siswa.

2. Kegiatan pemberian bahan remineralisasi dilakukan pada siswa di daerah pinggiran.

3. Adanya evaluasi terhadap peserta yang telah mendapatkan sosialisasi baik dari segi pengetahuan maupun dari kondisi gigi dan mulut.

\section{UCAPAN TERIMAKASIH}

Tim pengabdian pada masyarakat mengucapkan terima kasih kepada pihak LPPM USU yang telah memberikan dana kepada pengabdian ini. Terima kasih juga kepada pihak mitra yang telah koopratif di dalam pelaksanaan pengabdian ini.

\section{DAFTAR PUSTAKA}

Brown, JP, Dodds, MWJ. 2008. Dental Caries and Associated Risk Factors. In: Cappelli DP and Mobley CC. Prevention and Clinical Oral Health Care. Missuori: Mosby Elsevier

Casamassimo, PS., Fields, HW., Mc Tigue, DJ., Nowak, AJ. 2013. Pediatric Dentistry: Infancy Through Adolescence Fifth Edition. Missouri: Elsevier.

Mitchell, L. 2014. Kedokteran Gigi Klinik: Semua Bidang Kedokteran Gigi. Edisi 5. Jakarta: EGC. 
Fitri Yunita Batubara et.al. Prevention of dental caries

Reynolds EC, Cai F,Cochrane NJ, Shen P, Walker G, Morgan MV. Fluoride and casein phosphopeptide - amorphous calcium phosphate. J Dent Res 2004; 87:344-48.

Sumini., Amikasari, B., Nurhayati, D. 2014. Hubungan mengkonsumsi makanan manis dengan kejadian karies gigi pada anak prasekolah di TK B RA Muslimat PSM Tegalrejo Desa Semen Kecamatan Nguntoronadi Kabupaten Magetan, vol 3. Hal 20- 27. 